\title{
Evidence for Independent Hepatitis E Virus Replication in the Brain
}

Evert P.M. den Drijver, MD, Annemarie E. Brouwer, MD, PhD, Nathalie E. Synhaeve, MD, PhD, Janneke P. Keijer, MSc, Jaco J. Verweij, PhD, Jean-Luc Murk, MD, PhD, and Suzan D. Pas, PhD

Neurol Neuroimmunol Neuroinflamm 2021;8:e939. doi:10.1212/NXI.0000000000000939

\author{
Correspondence \\ Dr. den Drijver \\ evertdendrijver@gmail.com
}

\section{Case Report}

A 46-year-old man presented with a 5-year history of fatigue, frequent painful muscular spasms in the extremities, and tingling sensations in the hands and feet. His medical history consisted of attention-deficit/hyperactivity disorder, a cervical Mycobacterium avium lymphadenitis during childhood and lateral ligament reconstruction of both ankles after trauma.

Neurologic examination revealed hyperesthesia of arms and legs and inconsistent motor dysfunction without paresis. No muscle spasms were witnessed. During the examination, the patient showed inconsistent limb weakness without objective paresis as seen in patients with functional neurologic disorder. MRI reports of brain and spinal cord were unremarkable. EMG did not show any sign of polyneuropathy. CSF had 5 white blood cells $/ \mathrm{mm}^{3}$, no red blood cells, and normal protein $(0.36 \mathrm{~g} / \mathrm{L})$ and glucose $(3.4 \mathrm{mmol} / \mathrm{L})$ levels. Peripheral blood chemistry showed no abnormalities except for elevated gamma-glutamyl and alanine aminotransferases (GGT and ALT of 139 and $58 \mathrm{U} / \mathrm{L}$, respectively). Microbiological examinations provided detectable anti-hepatitis E virus (HEV)-immunoglobulin (Ig) M and IgG antibodies and HEV RNA in serum and CSF. Intrathecal antibody production of anti-HEV IgG was confirmed by calculation of the CSF-serum antibody index, being 7.5. Other hepatitis serology and HIV were negative. The patient did not use immunosuppressive drugs, and a basic immunologic screening did not reveal any immunodeficiencies, with $800 / \mathrm{mm}^{3} \mathrm{CD} 4$ cells and normal $\operatorname{IgA}$, IgM, and IgG subclass analysis. There were no signs of an underlying autoimmune disease and no history of recurrent infections.

Because it was expected that the immunocompetent man would clear the HEV infection, no treatment with ribavirin was started until it became evident at day 205 after the initial presentation that HEV RNA persisted in feces, plasma, and CSF (figure, A). After treatment was started at day 205, HEV RNA became undetectable in serum (day 236) and feces (day 282) and GGT and ALT levels normalized (figure, B). In CSF, however, HEV RNA remained detectable under ribavirin treatment for more than a year, with PCR cycle threshold values between 29.3 and 32.5, without a consistent decrease of viral load. The anti-HEV IgG CSF-serum antibody index increased to 30, which provided evidence for increased intrathecal IgG production (figure, A). Ribavirin plasma concentrations were within therapeutic levels (day $551,>2.00 \mathrm{mg}$ / L). PEG-interferon alpha 2a was added to ribavirin at day 567 because HEV RNA in CSF persisted and the patient showed only very limited signs of (subjective) improvement. Adding PEG-interferon alpha 2a did not result in clinical or virologic improvement, with HEV RNA in CSF still being present after 14 months of combined treatment. At day 991, it was decided to stop further treatment with ribavirin and PEG-interferon alpha 2a. After treatment was discontinued, HEV RNA in feces was tested at day 1,084 and in CSF and serum at day 1,089, with

From the Microvida (E.P.M.d.D., J.J.V., J.-L.M.), Department of Internal Medicine (A.E.B.), and Department of Neurology (N.E.S.), Elisabeth-TweeSteden Hospital, Tilburg; and Microvida (J.P.K., S.D.P.), Bravis Hospital, Roosendaal, The Netherlands.

Go to Neurology.org/NN for full disclosures. Funding information is provided at the end of the article.

The Article Processing Charge was funded by the authors.

This is an open access article distributed under the terms of the Creative Commons Attribution-NonCommercial-NoDerivatives License 4.0 (CC BY-NC-ND), which permits downloading and sharing the work provided it is properly cited. The work cannot be changed in any way or used commercially without permission from the journal. 
RNA in CSF still being present but no detectable RNA in serum or feces. Nonetheless, a follow-up MRI scan at day 1,109 was unremarkable.

\section{Virologic Analyses (Methods and Results)}

To determine if the CNS contained HEV quasispecies distinct from other bodily compartments, HEV RNA was sequenced from serum and CSF. HEV RNA from serum (day 12) and CSF (day 102) before antiviral treatment was Sangersequenced according to Sari et al., ${ }^{1}$ with minor adaptations. Near full genome (99.2\%) was obtained from serum (GenBank accession number MT362711). From CSF, 66.7\% of the genome could be retrieved due to low viral load (GenBank accession number MT362712). The genomes were genotype $3 \mathrm{c}$, and both showed a deletion in the polyproline-rich region in ORF1, a region known to affect and enhance viral adaptation. ${ }^{2}$ Notably, serum and CSF showed a 4 amino acid inframe deletion (del 733-736, PTPP), and CSF showed an additional 8 amino acid in-frame deletion (del 740-747, IRVLPPPS) compared with reference sequence KX172133 (figure, B and table e-1, links.lww.com/NXI/A367). The presence of a distinct viral population in the CNS in combination with viral persistence in the CSF strongly suggests independent viral replication of $\mathrm{HEV}$ in the brain. Ribavirin resistance-associated mutations were not found in samples obtained before treatment. ${ }^{3}$ After treatment, viral loads in CSF were below the detection limit for Sanger sequencing.

Figure HEV PCR Cycle Threshold Values (Serum, CSF, Faeces) and IgG Antibody Index

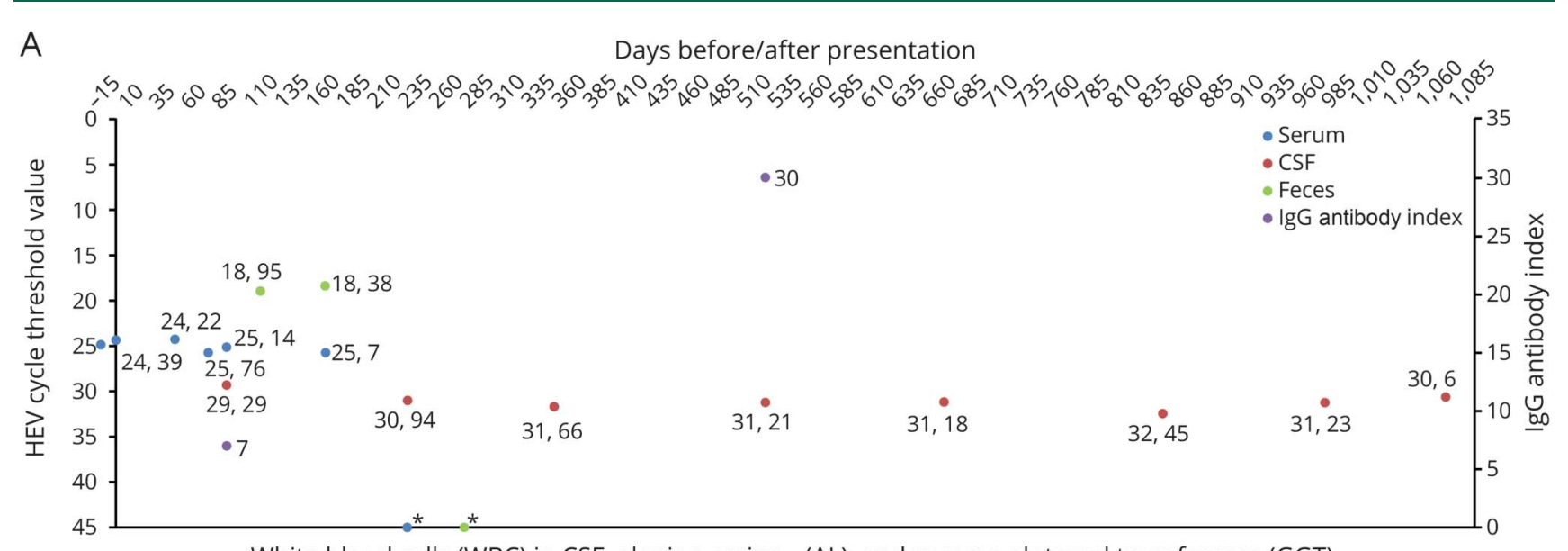

White blood cells (WBC) in CSF, alanine amino - (AL), and gamma-glutamyl transferases (GGT)

B

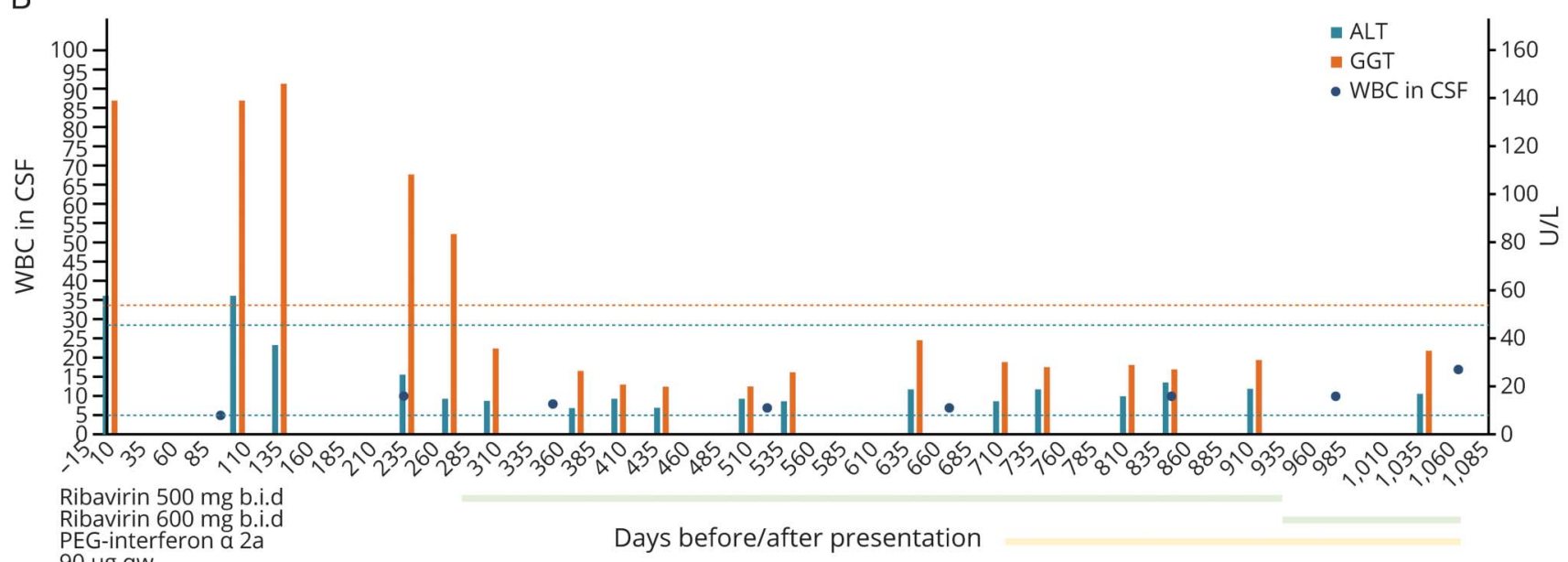

C

(P) 2 a

$90 \mu \mathrm{g}$ qw

Days before/after presentation

KX172133|HEV3C PAATPGLRHPTPPVSDIWVLPASSEELCVDTAP

HEVgt3c NL serum $906010 \ldots \ldots \ldots$. . . . . . R...............

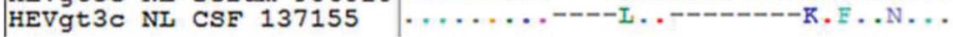

(A) Course of infection showing HEV RNA PCR cycle threshold values for serum, CSF, and feces and anti-HEV IgG antibody index values, (B) ALT and GGTs in blood vs WBC values in CSF, and (C) the alignment of reference, serum, and CSF sequence fragment with 4 amino acid in-frame deletion (del 733-736, PTPP) in serum and CSF. An additional 8 amino acid in-frame deletion (del 740-747, IRVLPPPS) in CSF. HEV = hepatitis E virus; IgG = immunoglobulin G. 


\section{Discussion}

Apart from hepatitis, HEV infections may also cause neurologic disorders, such as meningoencephalitis, peripheral neuropathies, and polyradiculitis. ${ }^{4}$ The etiology of HEVassociated neurologic manifestations is still inconclusive. If the HEV is primarily hepatotropic, the neurologic injury could be the result of postinfectious immune mechanisms. However, previous studies reported evidence for neurotropism of HEV, based on intrathecal anti-HEV antibody synthesis and CNS quasispecies compartmentalization of the HEV. ${ }^{4}$ Neurologic symptoms are often accompanied by the transient presence of HEV in CSF; however, it is unknown whether this is the result of a productive or abortive infection of cells in the nervous system. In the first scenario, the nervous system would support HEV replication independent of the rest of the body, whereas in the latter a localized infection cannot be sustained because infected cell types are incapable of completing the full viral replication cycle. The distinction is important because the possibility of a compartmentalized infection could lead to (unrecognized) viral persistence, clinical rebound of infection, treatment failure, and development of antiviral resistance. It also has implications for diagnostic testing and follow-up of patients.

Various human neural cell lines (embryonic stem cellderived neural lineage cells) have been shown to support in vitro HEV replication. ${ }^{5}$ In the present case, HEV was cleared from blood and feces on treatment with ribavirin, but HEV RNA persisted in the CSF for 1,089 days. In addition, the patient remained symptomatic and had evidence of CNS inflammation and progressively increasing intrathecal antibody synthesis. Although it could not be determined if HEV in CSF was infectious, this case provides direct evidence that the human CNS supports a persistent HEV infection possibly because of viral adaptation in the polyproline-rich region of ORF1.

The problems typical of compartmentalization are also evident in our case: treatment failure likely because of insufficient penetration of ribavirin in the nervous system. ${ }^{6} \mathrm{Un}$ fortunately, HEV RNA in CSF could not be tested for mutations associated with failure of ribavirin treatment during therapy because the viral load in CSF was too low. ${ }^{7}$ The prognosis of HEV persistence in the CNS is unknown.

In conclusion, we present a first case of chronic HEV RNA persistence and compartmentalization in CSF in an immunocompetent patient, suggestive of viral replication in the CNS. Our case also illustrates that new treatments are needed for persistent HEV infections.

\section{Acknowledgment}

The authors thank the patient for sample contribution and technicians of the Laboratory for Medical Microbiology and Immunology for contributions in diagnostics in the current case. The patient in this case report provided written informed consent for publication.

\section{Study Funding}

The authors report no targeted funding.

\section{Disclosure}

The authors report no disclosures relevant to the manuscript. Go to Neurology.org/NN for full disclosures.

\section{Publication History}

Received by Neurology: Neuroimmunology \& Neuroinflammation June 23, 2020. Accepted in final form November 9, 2020.

\section{Appendix Authors}

\begin{tabular}{|c|c|c|}
\hline Name & Location & Contribution \\
\hline $\begin{array}{l}\text { Evert P.M. } \\
\text { den Drijver, } \\
\text { MD }\end{array}$ & $\begin{array}{l}\text { Microvida, Elisabeth- } \\
\text { TweeSteden Hospital, } \\
\text { Tilburg, the Netherlands }\end{array}$ & $\begin{array}{l}\text { Drafting/revision of the } \\
\text { manuscript for content, } \\
\text { including medical } \\
\text { writing for content; } \\
\text { major role in the } \\
\text { acquisition of data; } \\
\text { study concept or design; } \\
\text { and analysis or } \\
\text { interpretation of data }\end{array}$ \\
\hline $\begin{array}{l}\text { Annemarie } \\
\text { E. Brouwer, } \\
\text { MD, PhD }\end{array}$ & $\begin{array}{l}\text { Department of Internal } \\
\text { Medicine, Elisabeth- } \\
\text { TweeSteden Hospital, } \\
\text { Tilburg, the Netherlands }\end{array}$ & $\begin{array}{l}\text { Drafting/revision of the } \\
\text { manuscript for content, } \\
\text { including medical } \\
\text { writing for content; and } \\
\text { major role in the } \\
\text { acquisition of data }\end{array}$ \\
\hline
\end{tabular}

\begin{tabular}{lll}
\hline Nathalie E. & Department of Neurology, & Drafting/revision of the \\
Synhaeve, & Elisabeth-TweeSteden & manuscript for content, \\
MD, PhD & Hospital, Tilburg, the & including medical \\
& Netherlands & writing for content; and \\
& major role in the \\
& acquisition of data
\end{tabular}

Janneke $\mathbf{P}$. Microvida, Bravis Hospital, Major role in the

Keijer, MSc Roosendaal, the Netherlands acquisition of data; and analysis or interpretation of data

\begin{tabular}{lll}
\hline Jaco J. & Microvida, Elisabeth- & Drafting/revision of the \\
Verweij, PhD & TweeSteden Hospital, & manuscript for content, \\
& Tilburg, the Netherlands & $\begin{array}{l}\text { including medical } \\
\text { writing for content; and } \\
\text { major role in the } \\
\end{array}$ \\
& acquisition of data
\end{tabular}

Jean-Luc Microvida, Elisabeth- Drafting/revision of the

Murk, MD, TweeSteden Hospital, manuscript for content, PhD Tilburg, the Netherlands including medical writing for content; major role in the acquisition of data; study concept or design; and analysis or interpretation of data

Suzan D. Pas, Microvida, Bravis Hospital, Drafting/revision of the
PhD Roosendaal, the Netherlands manuscript for content, including medical writing for content; major role in the acquisition of data; study concept or design; and analysis or interpretation of data 


\section{References}

1. Sari G, van de Garde MDB, van Schoonhoven A, et al. Hepatitis E virus shows more genomic alterations in cell culture than in vivo. Pathogens 2019;8:255. Available at: mdpi.com/2076-0817/8/4/255. Accessed February 25, 2020.

2. Purdy MA, Lara J, Khudyakov YE. The hepatitis E virus polyproline region is involved in viral adaptation. PLoS One 2012;7:e35974. Available at: dx.plos.org/10.1371/ journal.pone.0035974. Accessed February 25, 2020.

3. Debing $\mathrm{Y}$, Ramière $\mathrm{C}$, Dallmeier $\mathrm{K}$, et al. Hepatitis $\mathrm{E}$ virus mutations associated with ribavirin treatment failure result in altered viral fitness and ribavirin sensitivity. J Hepatol 2016;65:499-508. Available at: linkinghub.elsevier.com/retrieve/pii/ S0168827816301878. Accessed February 25, 2020.
4. Dalton HR, Kamar N, van Eijk JJJ, et al. Hepatitis E virus and neurological injury. Nat Rev Neurol 2016;12:77-85. Available at: nature.com/articles/nrneurol.2015.234. Accessed February 25, 2020. 5. Zhou X, Huang F, Xu L, et al. Hepatitis E virus infects neurons and brains. J Infect Dis 2017;215: 1197-1206. Available at: ncbinlm.nih.gov/pubmed/28199701. Accessed February 25, 2020.

6. Grayson ML, Cosgrove S, Crowe SM, et al. Kucers the Use of Antibiotics: A Clinical Review of Antibacterial, Antifungal, Antiparasitic, and Antiviral Drugs [online]. 7th ed. Boca Raton: CRC Press; 2017. Available at: taylorfrancis.com/books/ 9781444147520. Accessed February 25, 2020.

7. Todt D, Walter S, Brown R, Steinmann E. Mutagenic effects of ribavirin on hepatitis E virus-viral extinction versus selection of fitness-enhancing mutations. Viruses 2016;8: 283. Available at: mdpi.com/1999-4915/8/10/283. Accessed February 25, 2020. 


\section{Neurology \\ Neuroimmunology \& Neuroinflammation}

Evidence for Independent Hepatitis E Virus Replication in the Brain Evert P.M. den Drijver, Annemarie E. Brouwer, Nathalie E. Synhaeve, et al.

Neurol Neuroimmunol Neuroinflamm 2021;8;

DOI 10.1212/NXI.0000000000000939

This information is current as of January 5, 2021

\section{Updated Information \& Services}

References

Subspecialty Collections

Permissions \& Licensing

Reprints including high resolution figures, can be found at:

http://nn.neurology.org/content/8/2/e939.full.html

This article cites 6 articles, 0 of which you can access for free at: http://nn.neurology.org/content/8/2/e939.full.html\#\#ref-list-1

This article, along with others on similar topics, appears in the following collection(s):

Clinical neurology history

http://nn.neurology.org//cgi/collection/clinical_neurology_history

Encephalitis

http://nn.neurology.org//cgi/collection/encephalitis

Post-infectious

http://nn.neurology.org//cgi/collection/postinfectious_

Viral infections

http://nn.neurology.org//cgi/collection/viral_infections

Information about reproducing this article in parts (figures,tables) or in its entirety can be found online at:

http://nn.neurology.org/misc/about.xhtml\#permissions

Information about ordering reprints can be found online:

http://nn.neurology.org/misc/addir.xhtml\#reprintsus

Neurol Neuroimmunol Neuroinflamm is an official journal of the American Academy of Neurology.

Published since April 2014, it is an open-access, online-only, continuous publication journal. Copyright

Copyright $\left({ }^{\circ} 2021\right.$ The Author(s). Published by Wolters Kluwer Health, Inc. on behalf of the American

Academy of Neurology.. All rights reserved. Online ISSN: 2332-7812.

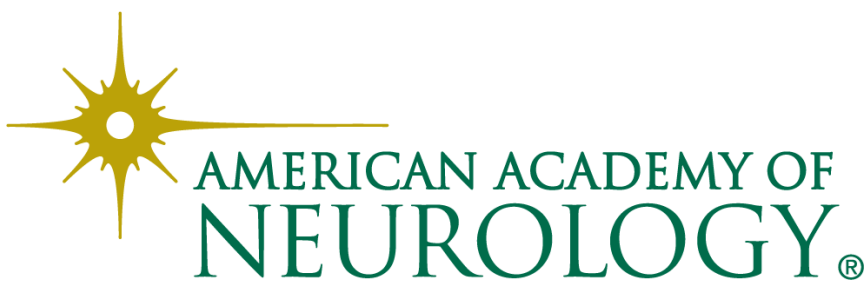

